\title{
KORELASI GLUKOSA DAN KETON DARAH PADA PASIEN UNIT GAWAT DARURAT DAN RAWAT INAP PENDERITA DIABETES MELITUS TIPE 2 DI RSAU DR. ESNAWAN ANTARIKSA JAKARTA
}

\author{
Ellis Susanti ${ }^{1{ }^{*}}$, Dara Masita ${ }^{2)}$, Imas Latifah ${ }^{3)}$ \\ 1)*DIII - Anafarma Universitas MH.Thamrin \\ ${ }^{2)}$ DIII-Analis Kesehatan Universitas MH.Thamrin \\ ellis.241289@gmail.com/0811189399
}

\begin{abstract}
ABSTRAK
Secara epidemiologi diperkirakan pada tahun 2030 prevalensi Diabetes Melitus (DM) di Indonesia mencapai 21,3 juta orang. Berdasarkan hasil Riset Kesehatan Dasar tahun 2013, prevalensi DM tertinggi terdapat di Yogyakarta (2,6\%), DKI Jakarta $(2,5 \%)$ dan Sulawesi Utara (2,4\%). Diabetes melitus merupakan penyakit kronik yang menyebabkan gangguan pada metabolisme, disebabkan kurangnya produksi insulin yang diperlukan dalam proses perubahan glukosa menjadi energi. Ketika tubuh tidak memiliki cukup glukosa, hati mengubah lemak menjadi keton. Berlebihnya keton yang ada di dalam darah disebut ketosis. Diabetes melitus tipe 2 paling banyak ditemukan di masyarakat. Terjadinya ketosis dan kemudian asidosis dapat menyebabkan kegawatan pada penyandang DM (ketoasidosis). Tujuan dilakukannya penelitian ini untuk mengetahui tingkat ketoasidosis pada pasien DM tipe 2 di unit gawat daraurat (UGD) dan rawat inap sehingga penanganannya dapat lebih tepat. Metode yang dilakukan yaitu observasi potong lintang, subyek penelitian sebanyak 86 orang DM tipe 2 di UGD dan rawat inap berdasarkan rekam medik. Hasil yang diperoleh korelasi lemah $(r=0,352, p=$ $0,007)$ pada pasien UGD dan korelasi cukup $(\mathrm{r}=0,570, \mathrm{p}=0,001)$ pada pasien rawat inap. Pada pasien UGD tidak mengalami ketoasi dosis berat dibandingkan dengan pasien rawat inap, antara lain berhubungan dengan durasi patofisiologi. Kesimpulan dan Saran yaitu pasien rawat inap harus dilakukan penatalaksanaan ketoasidosis yang lebih tepat.
\end{abstract}

Kata Kunci: DM tipe 2, Glukosa, Keton, Ketoasidosis

\section{PENDAHULUAN}

Berdasarkan data World Health Organization (WHO) memperkirakan jumlah penderita Diabetes di Indonesia akan terus melonjak, dari semula 8,4 juta penderita di tahun 2000 menjadi sekitar 21,3 juta di tahun 2030. Prevalensi DM di Indonesia meningkat dari tahun ke tahun. Penderita yang terkena bukan hanya berusia lanjut usia, namun banyak pula yang masih berusia produktif. Prevalensi DM berdasarkan diagnosis dokter dan gejala meningkat sesuai dengan bertambahnya umur, namun mulai umur $\geq 65$ tahun cenderung menurun. Prevalensi DM pada perempuan cenderung lebih tinggi dari pada laki-laki, di perkotaan cenderung lebih tinggi dari pada di pedesaan, serta cenderung lebih tinggi pada masyarakat dengan tingkat pendidikan tinggi dan dengan kuintil indeks kepemilikan tinggi (Kemenkes, 2013). Diabetes Melitus merupakan penyakit mematikan nomer 3 di Indonesia setelah penyakit Tuberkulosis (TBC) dan Jantung koroner (Depkes RI 2014). Data terbaru di tahun 2015 yang ditunjukkan oleh Perkumpulan Endokrinologi (PERKENI) menyatakan bahwa jumlah penderita Diabetes di Indonesia telah mencapai 9,1 juta orang. Kali ini Indonesia telah bergeser naik dari peringkat ke-7 menjadi peringkat ke-5 teratas diantara negara-negara dengan jumlah Diabetes terbanyak didunia. Hal ini tentu sangat memprihatinkan, karena Indonesia masih berada di urutan ke-10 pada tahun 2011 lalu (PERKENI, 2015). Diabetes melitus (DM) merupakan suatu penyakit kronik yang menyebabkan gangguan pada metabolisme karbohidrat, lemak dan protein sehingga tubuh tidak dapat menghasilkan insulin (hormon pengatur gula darah) atau insulin yang dihasikan tidak mencukupi atau insulin tidak bekerja dengan baik. Oleh karena itu akan menyebabkan gula darah meningkat saat diperiksa.Tingkat kadar glukosa darah menentukan apakah seseorang menderita diabetes atau tidak. Sekitar 90-95\% penderita diabetes melitus termasuk dalam diabetes tipe 2. 
Penderita dirawat dengan mengatur pola makan, latihan dan menyuntikkan insulin untuk mencapai kadar gula dan tekanan darah yang senormal mungkin (Sabella,2010). Pada DM tipe 2, disamping kadar glukosa tinggi, juga kadar insulin tinggi atau normal. Keadaan ini disebut resistensi insulin. Penyebab resistensi insulin pada DM tipe 2 sebenarnya tidak begitu jelas, tetapi faktor-faktor di bawah ini banyak berperan (Suyono, 2007 ) :

1. Obesitas terutama yang bersifat sentral (bentuk apel)

2. Diet tinggi lemak dan rendah karbohidrat

3. Kurang gerak badan

4. Faktor keturunan (herediter)

Diabetes Melitus tipe 2 umumnya terjadi lebih perlahan dan sering bahkan tidak diketahui adanya sampai bertahun-tahun. Walaupun demikian tidak berarti bahwa DM tipe 2 ini tidak berbahaya. Walau tidak ada keluhan, kalau tetap dibiarkan kadar glukosanya tinggi, tentu akan dapat menyebabkan terjadinya komplikasi yang dapat mengenai berbagai organ tubuh dan dalam jangka panjang tentu juga dapat menyebabkan kecacatan dan kematian. Banyak penyandang DM tipe 2 ini datang terlambat dan sudah mengidap komplikasi DM saat pertama kali diagnosis

Pada penderita DM tipe 2 terjadi gangguan metabolisme glukosa disebabkan kurangnya produksi hormon insulin yang diperlukan dalam proses perubahan gula menjadi tenaga serta sintesis lemak. Pemeriksaan glukosa darah sewaktu (GDS) diperlukan karena pasien yang datang ke rumah sakit tidak semua dalam kondisi yang memungkinkan untuk berpuasa terlebih dahulu sehingga dibutuhkan pemeriksaan yang bersifat segera. Glukosa darah yang terlalu tinggi dan kurangnya hormon insulin pada penderita diabetes melitus menyebabkan tubuh menggunakan lemak sebagai sumber energi. Hasil pemecahan lemak yaitu badan keton yang apa bila berlebihan dapat terdeteksi dalam darah dan urin (ketonuria). Keton adalah produksi simpangan dari metabolisme lemak. Ketika tubuh tidak memiliki cukup glukosa, hati mengubah lemak menjadi asam keton. Berlebihnya keton yang ada di dalam darah disebut ketosis (Utama, 2009). Ketoasidosis diabetik (KAD) merupakan defisiensi insulin berat dan akut dari suatu perjalanan Ketoasidosis diabetik adalah suatu kondisi gawat darurat yang merupakan komplikasi dari diabetes melitus yang ditandai dengan terjadinya hiperglikemia, asidosis dan ketosis. penyakit diabetes mellitus. Timbulnya KAD merupakan ancaman kematian bagi penyandang DM. Faktor yang mempengaruhi angka kematian tersebut adalah (Charles, 2011)

1. Terlambatnya ditegakkan diagnosis karena biasanya penyandang DM dibawa setelah koma.

2. Pasien belum tahu mengidap diabetes.

3. Sering ditemukan bersama-sama dengan komplikasi lain yang berat misalnya sepsis, renjatan, infark miokard.

4. Kurangnya fasilitas laboratorium yang menunjang penatalaksanaan ketoasidosis.

5. Kurangnya keterampilan menangani kasus-kasus ketoasidosis karena belum adanya protokol yang baik.

Berdasarkan pemaparan tersebut maka dilakukan penelitian dengan tujuan untuk mengetahui gambaran kadar dan korelasi glukosa darah sewaktu dan keton darah pada pasien di Unit Gawat Darurat (UGD) dan rawat inap pada penderita DM tipe 2, sehingga dapat menilai tingkat ketoasidosis pada pasien DM tipe 2 di unit gawat daraurat (UGD) dan rawat inap agar penanganannya dapat dilakukan dengan lebih tepat. 


\section{METODE}

Rancangan penelitian ini menggunakan metode observasi potong lintang. Subyek penelitian sebanyak 86 pasien DM tipe 2 di UGD dan rawat inap berdasarkan rekam medik. Populasi dan sampel penelitian adalah pasien penderita DM tipe 2 di RSPAU dr. Esnawan Antariksa Jakarta Timur periode bulan Mei 2015 hingga bulan April 2016. Teknik pengumpulan data dilakukan melalui tahapan pendataan terhadap pasien DM tipe 2 di UGD dan rawat inap RSPAU dr. Esnawan Antariksa berdasarkan rekam medik, melakukan pemeriksaaan glukosa darah sewaktu dan keton darah dan mengolah data hasil pemeriksaan. Teknik statistik berdasarkan perhitungan persentase terhadap distribusi frekuensi penderita DM tipe 2 berdasarkan usia, jenis kelamin. Kemudian menghitung rentang dan rerata hasil pemeriksaan glukosa dan keton serta terhadap nilai rujukan, menghitung rerata, rentang dan persentase hasil pemeriksaan glukosa darah sewaktu dan keton darah. Untuk menentukan korelasi, sebelumnya dilakuka uji normalitas. Sehubungan hasil berdistribusi normal maka dilanjutkan dengan menghitung korelasi menggunakan uji korelasi Pearson.

\section{HASIL}

Berdasarkan analisa hasil penelitian sebanyak 86 pasien DM tipe 2 di UGD dan rawat inap berdasarkan rekam medic di RSPAU dr. Esnawan Antariksa Jakarta Timur periode bulan Mei 2015 hingga bulan April 2016 didapat hasil sesuai pada gambar 1 .

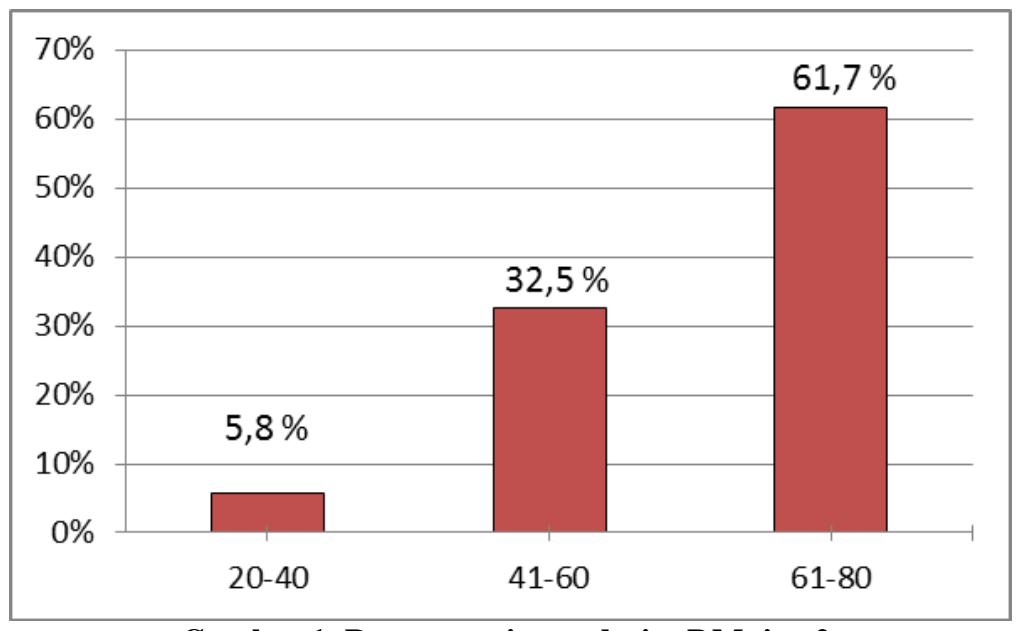

Gambar 1. Rentang usia penderita DM tipe 2

Distribusi frekuensi penderita DM tipe 2 berdasarkan usia,dengan rentanga 37-79 tahun. Terdapat 5,8\% pada usia 20-40 tahun, 32,5\% pada usia 41-60 tahun dan 61,7\% pada usia 61-80 tahun; Gambar 2. 


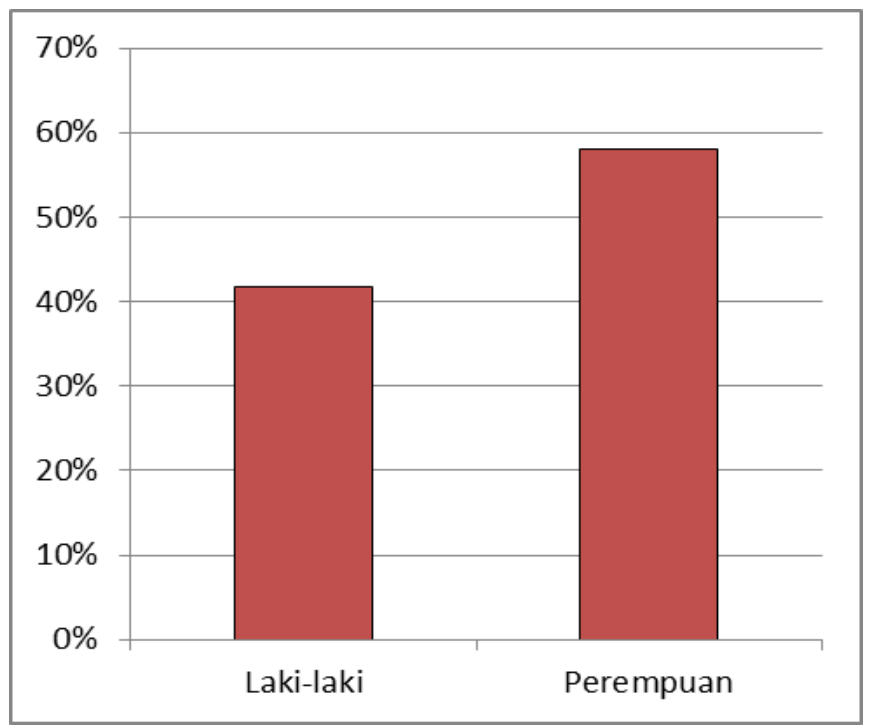

Gambar 2. Jenis kelamin penderita DM tipe 2

Jenis kelamin penderita DM tipe 2 Distribusi frekuensi penderita DM tipe 2 berdasarkan jenis kelamin, laki-laki sebanyak 41,8\% sedangkan perempuan sebanyak 58,2 \%; Gambar 3 .

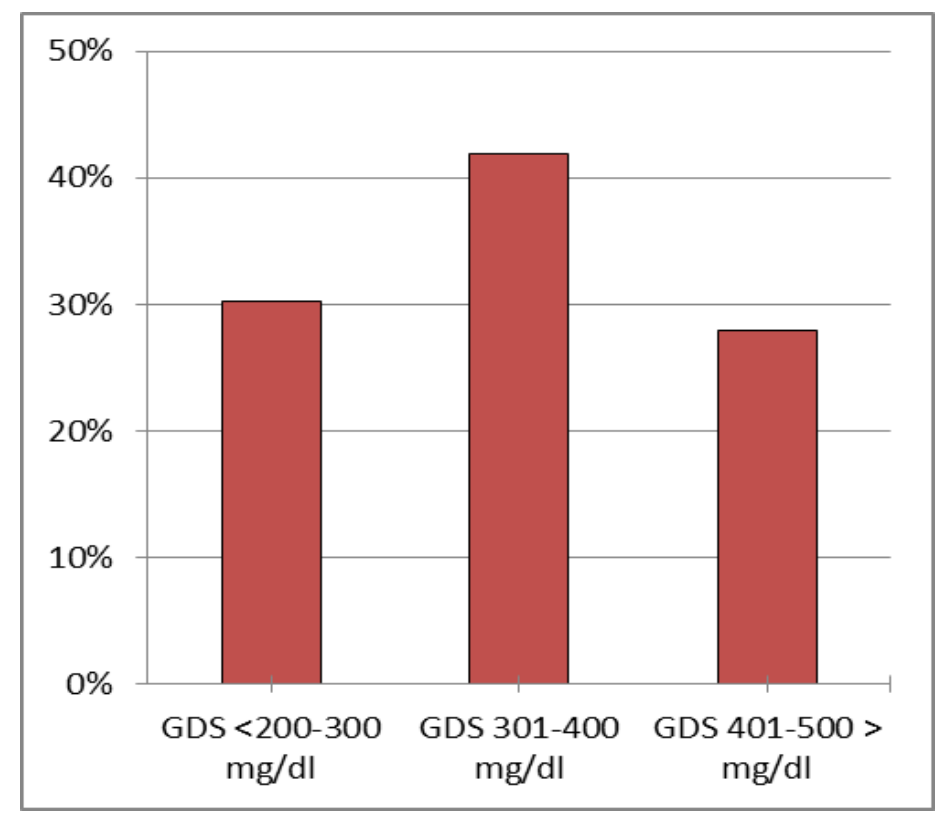

Gambar 3. Grafik Nilai GDS penderita DM tipe 2

Grafik Nilai GDS penderita DM tipe 2 Data pemeriksaan GDS terdapat kadar <200-300 mg/dl sebanyak 30,2\%, kadar 301-400 sebanyak 41,9\% dan kadar 401-500> sebanyak 27,9\%; Gambar 4. 


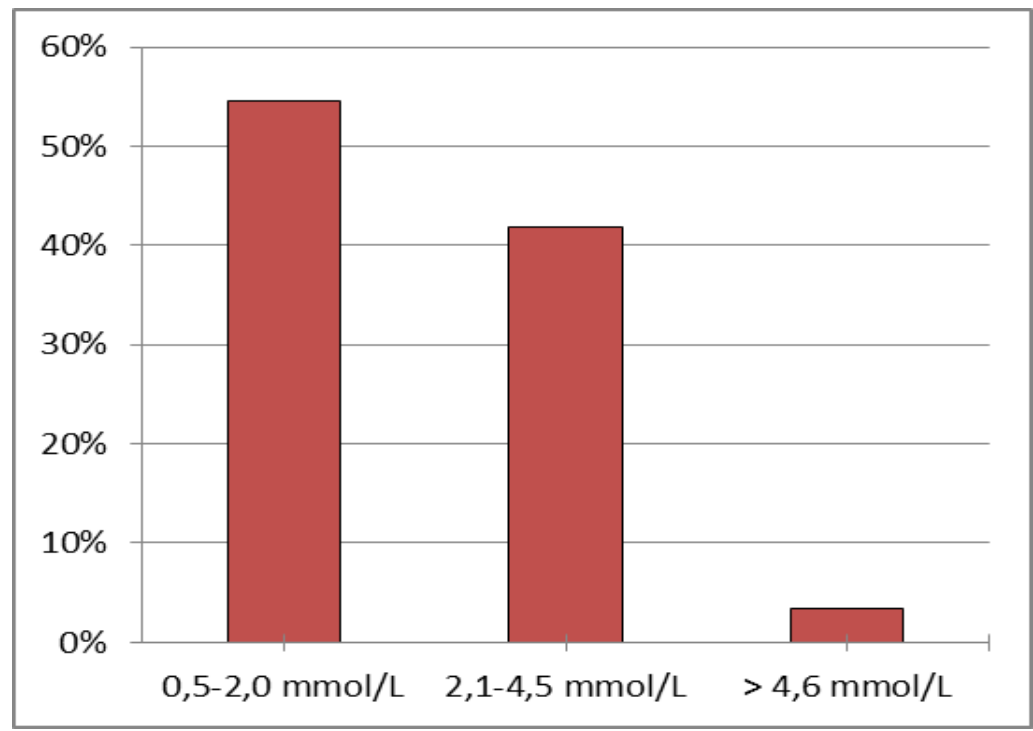

Gambar 4. Grafik Kadar Keton Darah penderita DM tipe 2

Grafik Kadar Keton Darah penderita DM tipe 2 Data pemeriksaan keton darah terdapat kadar 0,5-2,0 mmol/L sebanyak 54,6\%, kadar 2,1-4,5 mmol/L sebanyak 41,8\% dan kadar >4,6 mmol/L sebanyak 3,4\%; Tabel 1 Data rata-rata hasil pemeriksaan GDS pasien UGD yaitu $385 \mathrm{mg} / \mathrm{dl}$ sedangkan pada pasien rawat inap yaitu 268 $\mathrm{mg} / \mathrm{dl}$. Dan rata-rata hasil pemeriksaan Keton darah pada pasien UGD yaitu 2,4 mmol/L sedangkan pada pasien rawat inap yaitu $1,4 \mathrm{mmol} / \mathrm{L}$;

Tabel 1

Rata-rata Hasil Pemeriksaan GDS dan Keton Darah

\begin{tabular}{ccc}
\hline & UGD & Rawat Inap \\
\hline GDS & $385 \mathrm{mg} / \mathrm{dl}$ & $268 \mathrm{mg} / \mathrm{dl}$ \\
Keton Darah & $2,4 \mathrm{mmol} / \mathrm{L}$ & $1,4 \mathrm{mmol} / \mathrm{L}$ \\
\hline
\end{tabular}

Tabel 2 korelasi GDS dan Keton Darah didapat korelasi lemah $(r=0,352, p=0,007)$ pada pasien UGD dan korelasi cukup $(\mathrm{r}=0,570, \mathrm{p}=0,001)$ pada pasien rawat inap.

Tabel 2

Korelasi GDS dan Keton Darah

\begin{tabular}{cccc}
\hline & R & P & KORELASI \\
\hline UGS & 0,382 & 0,007 & LEMAH \\
Rawat Inap & 0,570 & 0,001 & CUKUP \\
\hline
\end{tabular}

\section{PEMBAHASAN}

Berdasarkan usia yang paling banyak menderita DM tipe 2 yaitu pada usia 61-80 tahun. Hal ini disebabkan terjadinya peningkatan intoleransi glukosa, adanya proses penuaan menyebabkan berkurangnya kemampuan sel $\beta$ pankreas dalam memproduksi insulin selain itu terdapat penurunan aktivitas mitokondria di sel-sel otot sebesar 35\%, hal ini berhubungan dengan peningkatan kadar lemak di otot sebesar 30\% dan memicu terjadinya resistensi insulin. Selanjutnya pada usia rentang 41-60 tahun fungsi tubuh secara fisiologis menurun karena terjadi penurunan sekresi atau resistensi insulin sehingga kemampuan fungsi tubuh terhadap pengendalian glukosa darahnya tinggi (Husin, 2015). Dan yang terakhir pada usia rentang 20-40 tahun merupakan usia produktif, banyak terjadi dikarenakan pengendalian pola hidup kurang sehat, stres dan kurangnya edukasi 
terhadap penyakit DM yang dideritanya, kegemukan (obesitas) menyebabkan jaringan lemak menumpuk, jaringan tubuh dan otot akan makin resisten terhadap kerja insulin, terutama bila lemak tubuh at au kelebihan berat badan terkumpul didaerah sentral atau perut. Lemak ini akan memblokir kerja insulin sehingga glukosa tidak dapat diangkut kedalam sel dan menumpuk dalam peredaran darah. (Trisnawati, 2013).

Berdasarkan jenis kelamin didominasi oleh perempuan yaitu 50 orang $(58,1 \%)$ sedangkan pada laki-laki berjumlah 36 orang $(41,8 \%)$. Ini disebabkan karena secara fisik wanita memiliki peluang peningkatan indeks masa tubuh yang lebih besar, bahkan pada wanita yang sudah tua (lebih dari 40 tahun) dan telah mengalami manopause mempunyai kecenderungan untuk lebih tidak peka terhadap hormon insulin. Diabetes secara umum untuk laki-laki datang lebih cepat dari perempuan, perempuan bisa terlindungi dari DM sampai mencapai usia menopouse karena pengaruh hormon wanita estrogen, yaitu hormon reproduksi yang membantu mengatur gula darah dalam tubuh (Trisnawati, 2013).

Pemeriksaan GDS mempunyai nilai yang bervariatif. Didapat hasil yang tertinggi yaitu $301-400 \mathrm{mg} / \mathrm{dl}$ sebanyak 41,9\% dan merupakan suatu pengendalian GDS yang buruk untuk penderita DM sehingga sangat beresiko terjadinya komplikasi bila GDS tidak terkontrol dengan baik. Sedangkan sebanyak 30,2\% dengan rentang GDS $<200-300 \mathrm{mg} / \mathrm{dl}$ dengan pengendalian yang cukup baik atau sedang melalui proses pengobatan. Dan sisanya sebanyak 26,8\% dengan rentang GDS 401-500> mg/dl merupakan penderita yang sangat berpotensi atau bahkan sudah mengalami komplikasi.

Berdasarkan rentang nilai keton darah didapat 54,6\% yang mengalami ketosis ringan dan 41,8\% mengalami ketosis sedang serta sisanya sebanyak 3,4\% mengalami ketosis berat. Benda keton diproduksi ketika karbohidrat tidak dapat digunakan untuk menghasilkan energi yang disebabkan oleh gangguan metabolisme karbohirat, kurangnya asupan karbohidrat (kelaparan, diet tidak seimbang seperti tinggi lemak rendah karbohidrat), gangguan absorbsi karbohidrat, gangguan mobilisasi glukosa, sehingga tubuh mengambil simpanan asam lemak untuk dibakar. Ketosis yang berat sangat berpotensi menyebabkan komplikasi dalam bentuk asidosis pada penderita DM, peningkatan kadar keton dalam darah akan menimbulkan ketosis sehingga dapat menghabiskan cadangan basa (misal bikarbonat, $\mathrm{HCO}_{3}$ ) dalam tubuh dan menyebabkan asidosis (Utama, 2009).

Dari seluruh pasien didapat pasien UGD yang memiliki nilai rata-rata GDS tertinggi yaitu $385 \mathrm{mg} / \mathrm{dl}$ dan ratarata Keton darah yaitu 2,4 mmol/L. Sedangkan pada rawat inap nilai GDS yaitu $268 \mathrm{mg} / \mathrm{dl}$ dan keton darah 1,4 $\mathrm{mmol} / \mathrm{L}$. Kadar rawat inap lebih rendah karena pasien telah menjalani perawatan untuk kelangsungan penyembuhan penyakit, pemberian perawatan yang terbaik seperti pelayanan gizi sesuai dengan keadaan pasien (Wijaya, 2010)

Korelasi GDS dan keton darah pada pasien UGD memiliki nilai $r=0,352, p=0,007$ yang dapat dikategorikan memiliki hubungan yang lemah karena pasien yang datang ke UGD yaitu pasien dengan keluhan kondisi tubuh yang sakit secara mendadak atau penurunan kesadaran yang harus ditangani segera karena kadar glukosa yang tidak terkontrol (Kartikawati, 2015).

Metabolisme glukosa diatur oleh hormon insulin yang dikeluarkan oleh pankreas. Apabila seseorang kekurangan insulin, maka kadar glukosa akan meningkat, tetapi tidak dapat digunakan oleh sel karena tidak dapat diubah menjadi glukosa -6 - fosfat. Hal tersebut dialami oleh penderita diabetes. Oleh karena sel tidak 
dapat menggunakan glukosa, maka energi yang diperlukan diperoleh dari penguraian lemak dan metabolisme protein. Sebagai akibat pembentukan asetil koenzim A bertambah banyak dan hal ini menyebabkan terbentuknya senyawa keton secara berlebih (Waspaji, 209). Sedangkan pasien pada rawat inap kadar glukosa dapat terkontrol, kadar keton terbentuk tergantung pada diet dan lamanya komplikasi sehingga korelasi GDS dan keton darahpada pasien Rawat Inap memiliki nilai $r=0,570, p=0,001$ yang dapat dikategorikan memiliki hubungan yang cukup.

\section{KESIMPULAN DAN REKOMENDASI}

Dari hasil penelitian hubungan kadar glukosa dan keton darah pasien UGD dan Rawat Inap terhadap 86 penderita Diabetes Melitus tipe 2 di RSAU dr. Esnawan Anariksa pada bulan Mei 2015-April 2016 dapat ditarik kesimpulan bahwa pasien DM tipe 2 terbanyak diderita pasien perempuan yaitu 50 orang $(58,1 \%)$.dengan usia 61-80 tahun sebanyak 53 orang (61,6\%); dari seluruh pasien didapat pasien UGD yang memiliki nilai rata-rata GDS tertinggi yaitu $385 \mathrm{mg} / \mathrm{dl}$ dan Keton darah 2,4 mmol/L; Pada pasien UGD tidak mengalami ketoasidosis berat dibandingkan dengan pasien rawat inap; Pada pasien rawat inap harus dilakukan penatalaksanaan ketoasidosis yang lebih tepat. Saran Setelah dilakukan penelitian lanjut terhadap kondisi DM tipe 2 terkontrol dan tidak terkontrol untuk dapat memastikan faktor risiko terhadap komplikasi DM

\section{REFERENSI}

1. Boedisantoso, R dan Subekti imam. 2009.Komplikasi Akut Diabetes Mellitus, Jakarta,FKUI.

2. Charles, Fox. 2011. Bersahabat dengan Diabetes Tipe 2. Jakarta : Jakarta Penebar Plus Husin. 2015. Pemeriksaan Analis Gas Darah pada penderita DM untuk mencegah terjadinya komplikasi Ketoasidosis di RSUD Koja Jakarta. Universitas MH. Thamrin Jakarta.

3. Kartikawati, N. Dewi. 2015. Buku Ajar Dasar-dasar Keperawatan Gawat Darurat. Salemba Medika: Jakarta.

4. Kemenkes. Riset Kesehatan Dasar: Riskesdas 2013. Jakarta: Badan Penelitian dan Pengembangan Kesehatan Kementrian Kesehatan RI. 2013.

5. Perkumpulan Endrorinologi Indonesia (PERKENI), 2015, Konsensus Pengendalian dan Pencegahan Diabetes Melitus Tipe2 di Indonesia 2015, PERKENI, Jakarta.

6. Sabella, Rifdah. 2010. Libas Diabetes Dengan Terapi Herbal, Buah Dan Sayur. Yogyakarta : Galmas publisher.

7. Suryono,Slamet, dkk.2009. Buku Ajar Ilmu Penyakit Dalam. Internal Publishing. Jakarta.

8. Trisnawati, Shara K, dkk. 2013. Faktor Risiko Kejadian Diabetes Melitus Tipe 2 Di Puskesmas Kecamatan Cengkareng Jakarta Barat Tahun 2012. Jurnal Ilmiah Kesehatan Vol.5 No.1:1-11.

9. Utama, hendra. 2009. Ilmu Penyakit Dalam. Jakarta : Balai Penerbit FKUI.

10. Waspaji,S. 2009, Indeks Glikemik Berbagai Makanan Indonesia, penerbit FKUI. Jakarta. Wijaya, S. 2010. Konsep Dasar Keperawatan Gawat Darurat. Denpasar : PSIK FIK UNUD. 